WIESLAW P. TEKELY

\title{
Skarbowość na ziemiach polskich $w$ dobie zaborów - stan badań
}

\author{
Staatsfinanzen der polnischen Gebiete zur Zeit \\ der drei Teilungen Polens - Stand der Forschung
}

1. Stan badań nad skarbowością na ziemiach polskich - kryteria selekcji, analiza $\mathrm{i}$ ocena. 2. Zestawienie bibliograficzne $w$ układzie terytorialnym. 3. Zestawienie bibliograficzne w układzie merytorycznym.

1. Stand der Forschung zu den Staatsfinanzen in den polnischen Gebieten - Kriterien der Auswahl, Analyse und Bewertung. 2. Bibliographie nach Territorien geordnet. 3. Inhaltliche Bibliographie.

1. Podejmując próbę oceny stanu badań nad skarbowością na ziemiach polskich w dobie zaborów, trzeba przyjąć określone kryteria, dzięki którym można dokonać wyboru dorobku nauk historycznoprawnych $w$ interesującym zakresie. Przyjęto następujące założenia:

1) brano pod uwage wyłącznie opracowania dotyczące instytucji funkcjonujących na ziemiach polskich, nie wchodząc w problematykę skarbowości państw zaborczych (o ile nie stanowiła ona punktu odniesienia dla wskazania różnic w rozwiązaniach stosowanych na ziemiach polskich);

2) ujęto prace dotyczące administracji skarbowej, problematyki: budżetowej, podatkowej, finansów publicznych, cel, kontroli skarbowej, systemu bankowego, towarzystw kredytowych i kas oszczędnościowych. Tematyka ta była ujeta $w$ tytule opracowania jako nurt rozważań autora - nie zaś tylko drobną ich część. Nie dotyczy to rzecz jasna tak fundamentalnego dzieła, jak Finanse Królestwa Polskiego... J. Blocha;

3) starano się nie wchodzić głębiej w problematykę prawa finansowego, gospodarczego i handlowego oraz systemu bankowego, ograniczając się w tym zakresie do niezbędnego minimum;

4) nie brano pod uwage licznych (głównie XIX-wiecznych) jedno- czy dwustronicowych przyczynków publikowanych w prasie. 
Opracowania spełniające te warunki dotyczą skarbowości Księstwa Warszawskiego, Królestwa Polskiego, Wolnego Miasta Krakowa, Galicji, Wielkiego Księstwa Poznańskiego. Oceniając zgromadzony material (156 pozycji), można jednoznacznie stwierdzić, że zdecydowanie przeważaja prace poświęcone Księstwu Warszawskiemu i Królestwu Polskiemu (89), najmniej zaś dotyczy analizy porównawczej lub problematyki dotyczącej więcej niż jednego obszaru ziem polskich - jest ich zaledwie 11. Niewiele więcej (12) dotyczy ziem polskich związanych z Prusami.

Jeżeli zaś chodzi o układ merytoryczny, to najwięcej prac poświęcono problematyce budżetów, podatków i finansów (69), przy czym większość stanowią drobniejsze przyczynki. Zastanawiająco mało (tylko 13) jest opracowań dotyczących administracji skarbowej. Tutaj otwierają się największe płaszczyzny badawcze dla wspólczesnych historyków administracji i ustroju.

Generalny wniosek, jaki nasuwa się z przedstawionego poniżej zestawienia, jest taki, że problematyka skarbowości w okresie zaborów nie była częstym tematem badawczym wspólczesnych nam historyków; w okresie ostatnich 30 lat opublikowano zaledwie 23 pozycje. Tylko kilka $z$ nich ma charakter dogłębnego przedstawienia podjętej problematyki: prace $\mathbf{M}$. Wąsowicza dotyczące Prokuratorii Generalnej oraz R. Szawłowskiego, który opracował system organów kontroli skarbowej. Większość prac stanowią przyczynki będące marginesem szerszych rozważań lub, co najwyżej, zapowiedź większej całości - problematyka celna w ujęciu W. P. Tekely'ego.

Mając nadzieję, że zamieszczone poniżej zestawienie będzie zachętą do podjęcia badań, przygotowano je w dwóch ujęciach, by ułatwić odnalezienie interesujących pozycji. Pierwsze ujęcie - terytorialne - podzielono na cztery części: - opracowania dotyczące calości ziem polskich, - Księstwa Warszawskiego i Królestwa Polskiego, - Galicji i Wolnego Miasta Krakowa oraz - Wielkiego Księstwa Poznańskiego (Śląska i Pomorza Gdańskiego). Drugie ujęcie - merytoryczne - podzielono na sześć części: a administracja; - banki, towarzystwa kredytowe i kasy oszczędnościowe; - problematykę celną; - organy kontroli; - budżet, podatki i finanse; - inne.

\section{2. [UJĘCIE TERYTORIALNE]}

- Opracowania dotyczące całości ziem polskich:

[1] Baliński I., Loterie publiczne w Polsce. Szkic historyczny, Warszawa 1918.

[2] Czermiński F., Towarzystwa kredytowe ziemskie ze szczególnym wzgledem na takież towarzystwa $w$ Wielkim Księstwie Poznañskim, Królestwie i Galicji, Warszawa 1867.

[3] Grodek A., Idea Banku Narodowego. (Geneza Banku Polskiego 1763-1828), Warszawa 1936.

[4] Jezierski A., Bankowość polska na tle przemian gospodarczych u schylku $X I X$ i na poczqtku $X X$ wieku, „Bank i Kredyt” 2000, nr 11. 
[5] Kula W., Polskie perypetie metrologiczne (1795-1919), [w:] Wiek XIX. Prace ofiarowane S. Kieniewiczowi w 60 rocznice urodzin, Warszawa 1967.

[6] Markowski B., Administracja skarbowa w Polsce, Warszawa 1931.

[7] Rybarski S., Skarbowość Polska w dobie zaborów, Kraków 1937.

[8] Waszkiewicz J., Historya banków oraz celniejszych towarzystw kredytowych, Wilno 1838.

[9] Zamoyski G., Prawne podstawy funkcjonowania komunalnych kas oszczedności na ziemiach polskich w okresie zaborów, [w:] Przez tysiaclecia: państwo - prawo - jednostka, t. 2, Katowice 2001.

[10] Zieliński F., Poszukiwania nad finansami w Polsce, „Biblioteka Warszawska" 1849.

[11] Ziembiński J., Polska kontrola państwowa $w X I X$ w. $i w$ Drugiej Rzeczypospolitej, „Acta Universitatis Nicolai Copernici” 1985, Prawo, nr 24.

- Księstwo Warszawskie i Królestwo Polskie:

[1] Ajzen M., Polityka gospodarcza Lubeckiego 1821-1830, Warszawa 1932.

[2] Bagniewski A., O mennicy warszawskiej od czasu jej zalożenia (1810) do roku 1867, ze szczególnym względem na monete zdawkowa, „Ekonomista" 1869 , t. 1.

[3] Bagniewski A., O stanie finansów Królestwa Polskiego, „Biblioteka Warszawska" 1861, t. 2.

[4] Bagniewski A., O zastosowaniu towarzystw kredytowych ziemskich do nieruchomości miejskich, mianowicie w mieście Warszawie, „Biblioteka Warszawska" 1842, t. 2.

[5] Bielski A., Projekt do ustawy kassy amortyzacyjnej, Rawicz 1811.

[6] Bielski A., Sposoby do ocalenia majatków obywateli Ksiestwa Warszawskiego, Kalisz 1809.

[7] Bloch J., Finanse Królestwa Polskiego za caly czas istnienia skarbu Królestwa od dnia 1 czerwca 1815 do 31 grudnia 1866 r. Zarzad, wladze skarbowe $i$ reforma podatkowa $w$ Królestwie Polskim, [w:] J. Bloch, Finanse Rosji w XIX wieku na tle cywilnych dziejów państwa, t. 3, Warszawa 1883.

[8] Bloch J., Reforma podatkowa w Królestwie Polskim podlug badań..., „Ekonomista" 1879, nr 48-52.

[9] Borzymińska Z., Sprawa podatku szynkarskiego w Warszawie w latach 1862-1866, „Biuletyn ŻIH” 1988, nr 2.

[10] Bossakowski J., Gospodarka i finanse Królestwa Polskiego przed powstaniem styczniowym. Raport... z $1862 \mathrm{r}$. dla ministra finansów $M$. Ch. Reuterna, oprac. R. Kolodziejczyk, Warszawa 1969.

[11] Boufall B., Gospodarka finansowa zarzqdów miejskich $w$ Królestwie Polskim ( $z$ wyjatkiem Warszawy), Warszawa 1905. 
[12] Budziński S., O stosowaniu ustawy celnej $z$ r. 1857, a w szczególności art. 1621 i 1622 tejże ustawy, „Gazeta Sądowa” 1880, nr 48-50.

[13] Ćwik W., Sprawa oplat za prawo miejskie w Królestwie Polskim, "Czasopismo Prawno-Historyczne" 1972, t. 24, z. 1.

[14] Falkenhagen-Zaleski P., $O$ instytucjach kredytowych $w$ kraju naszym, Warszawa 1861.

[15] Gliszczyński A., Uwagi nad dochodami publicznymi, Warszawa 1810.

[16] Gliszczyński A., Uwagi nad projektem amortyzacji dlugów ziemiańskich $w$ departamencie bydgoskim, Bydgoszcz 1811.

[17] Górski S., Gospodarka finansowa miasta Warszawy, dodatek do: „Biblioteka Warszawska" 1906, nr 6, 7.

[18] Grabski W., Bilans Królestwa Polskiego w finansach państwa rosyjskiego, Warszawa 1909.

[19] Grabski W., Ciężary samorzq̨du w Królestwie Polskim, Warszawa 1908.

[20] Grabski W., Dzialalność państwowa wobec potrzeb rolniczych Królestwa Polskiego. Co skarb państwa w naszym kraju na cele rolnicze wydaje i czego domagać sie winniśmy i możemy, Warszawa 1909.

[21] Grabski W., Sprawa podatku od dochodu z nieruchomości miejskich w Królestwie Polskim, Praca nr 5, dodatek do: „Biblioteka Warszawska” 1909 , t. 3.

[22] Groniowski K., Bank Wlościański w Królestwie Polskim, „Przegląd Historyczny" 1984, nr 1.

[23] Grzegorzewski M., Reforma kas gminnych pożyczkowo-oszczędnościowych w Królestwie Polskim, Kielce 1907.

[24] Jaworski J., Gospodarka finansowa zarząów miejskich w Królestwie Polskim z wylaczeniem Warszawy, Warszawa 1906.

[25] Jezierski A., Bank Polski 1828-1885, „Bank i Kredyt” 1988, nr 5/6.

[26] Karbownik H., Opodatkowanie duchowieństwa i dóbr kościelnych w Królestwie Polskim (1815-1863), „Roczniki Teologiczno-Kanoniczne” 1989/90 (1993), nr 36/37, z. 5.

[27] Kempner S., Prawa stanowe kupców w Królestwie Polskim, w zwiqzku z prawodawstwem podatkowym, „Gazeta Sąowa” 1899, nr 8-10.

[28] Kirszrot-Prawnicki J., Towarzystwo Kredytowe Ziemskie w Królestwie Polskim i kredyt rolny, Warszawa 1887.

[29] Kisiel H., Akta zarzqdu dóbr państwowych w Radomiu, „Archeion” 1962 , t. 36.

[30] Korzybski Z., O kredycie $i$ bankach emisyjnych z zastosowaniem do potrzeb kraju naszego, Warszawa 1862.

[31] Kurc A., O kasach oszczędności, „Biblioteka Warszawska” 1842, t. 1.

[32] Kurtz A., O cyrkulacji pienięznej w Królestwie Polskim, „Ekonomista" 1865 , kwart. 4, z. 1 [Miaskowski F.] F. M., Odpowiedź na memorial pana Adolfa Kurtza, O cyrkulacji pienięznej w Królestwie Polskim, 
zamieszczony w I-m i III-m zeszycie Ekonomisty, „Ekonomista” 1865, kwart. 4, z. 3.

[33] Kurtz A., Rzecz o cyrkulacji pieniężnej $i$ walucie w Królestwie Polskim, Warszawa 1866.

[34] Lewin D., Obieg pieniężny Królestwa Kongresowego w drugiej polowie $X I X$ stulecia, „Rocznik Wyższej Szkoly Handlowej w Warszawie” 1929, R. VI.

[35] Letowski L., $O$ moratoryum, Warszawa 1816.

[36] Marcinek R., Komora celna w Szycach pod Krakowem, ,Teki Krakowskie” 1998, z. 8.

[37] Markowski B., Finanse miast Królestwa Polskiego, t. 1, Kielce 1913.

[38] Mayzel B., Nowy podatek, „Gazeta Sądowa” 1879, nr 27-31.

[39] Mikulec B., Spóldzielcze towarzystwa pożyczkowo-oszczednościowe i kredytowe w guberni lubelskiej w latach 1898-1914, „Rocznik Lubelski” $1985 / 86$ (1988), t. 27/28.

[40] Mikulicz-Radecki A., O podatku gruntowym dworskim w Królestwie Polskiem, Warszawa 1884.

[41] Mirecki W., $O$ prawodawstwie $i$ administracji finansowej, ,Dekada Polska" 1821, t. 1, nr 4-6.

[42] Plewako G., Henryk hr. Lubieński i Benedykt Niepokojczycki - dwaj kierownicy Banku Polskiego. Przyczynek do dziejów tegoż Banku (1831-1865), „Niwa” 1887, t. 31.

[43] Polujański A., Najwyższa Izba Obrachunkowa Królestwa Polskiego od 1808 do 1866 r. wlacznie, „Biblioteka Umiejętności Prawnych” 1880, z. $42-44$.

[44] Polujański A., Opisanie lasów Królestwa Polskiego i guberni zachodnich Cesarstwa Rosyjskiego pod wzgledem historycznym, statystycznym i gospodarczym, t. 1-4, Warszawa 1854-1855.

[45] Połujański A., Przepisy tyczace się egzekucji podatków w Królestwie Polskim, Warszawa 1883.

[46] Popiel I., Towarzystwo Kredytowe Ziemskie w Królestwie Polskim. Kilka uwag zebral..., Warszawa 1901.

[47] Powichrowski W., O powinności podwodowej w Królestwie Polskim, „Gazeta Sądowa” 1893, nr 6, 7, 10.

[48] Przygodzki J., Sprawy finansowe Ksiestwa Warszawskiego pod okupacja rosyjskq $w$ latach 1813-1815, „Acta Uniwersitatis Wratislaviensis" 2000, Prawo, nr 270.

[49] Radziszewski H., Bank Polski, Warszawa 1910.

[50] Radziszewski H., Podatki gruntowe w Królestwie Polskim, [w:] $W$ naszych sprawach, t. 1, Warszawa 1899.

[51] Radziszewski H., Reorganizacja Banku Polskiego po rewolucji listopadowej, „Przegląd Narodowy” 1910, t. 6, z. 7. 
[52] Radziszewski H., „Reorganizacya” skarbu Królestwa Polskiego po powstaniu listopadowym, „Przegląd Narodowy” 1908, t. 1, z. 4.

[53] Radziszewski H., Skarb i organizacja wladz skarbowych $w$ Królestwie Polskim, t. 1 (1815-1830), t. 2 (1831-1867), Warszawa 1907 (t. 1), 1908 (t. 2).

[54] Radziszewski H., Wydatki skarbu Królestwa Polskiego w okresie międzypowstaniowym, ,Przegląd Narodowy” 1908, t. 2, z. 7.

[55] Radziszewski H., Zniesienie linii celnej pomiędzy Królestwem Polskim a Cesarstwem Rosyjskim w roku 1850, dodatek do: „Biblioteka Warszawska" 1907, nr 6.

[56] Rembowski A., Nowe prawo o urządzeniu gruntowym wiejskich czynszowników, „Niwa” 15 I 1880.

[57] Romanowski J., Rys stosunków ekonomicznych guberni radomskiej na podstawie akt hipoteki gubernialnej $i$ akt notaryalnych $w$ Radomiu, Warszawa 1892.

[58] Rostocki W., Ludzie Colomba w Ministerium Skarbu u schylku Księstwa Warszawskiego, [w:] Wiek XIX, Warszawa 1967.

[59] Rostworowski M., Prawno-polityczna strona budżetów Królestwa Kongresowego (1816-1830), „Czasopismo Prawnicze i Ekonomiczne” 1905, R. VI.

[60] Rzepniewska D., Dobry kredyt i lichwa w Królestwie Polskim XIX w., [w:] Drobnomieszczaństwo XIX i XX wieku, t. 1, Warszawa 1984.

[61] Skarbek F., Gospodarstwo narodowe stosowane, Warszawa, 1860.

[62] Skarbek F., Gospodarstwo narodowe, Warszawa 1820/21.

[63] Stankiewicz Z., Reformy czynszowe dóbr skarbowych w Królestwie Polskim, Łódź 1968.

[64] Stankiewicz Z., System eksploatacji dóbr publicznych w Polsce środkowej w okresie przejścia od feudalizmu do kapitalizmu, „Czasopismo Prawno-Historyczne" 1970, t. 22, z. 2.

[65] Stanulewicz M., Polityka fiskalna wladz powstania styczniowego w świetle dekretów Rzqdu Narodowego, [w:] Studia $z$ historii ustroju $i$ prawa Ksiega dedykowana Prof. Jerzemu Walachowiczowi, red. H. Olszewski, Poznań 2002.

[66] Stawiarski J. F., Uwagi nad moratorium, Warszawa 1816.

[67] Strasburger A., Podręcznik o kosztach stemplowych $i$ innych optatach, wnoszonych od dn. 1 maja $1884 \mathrm{r}$. przy sporzqdzaniu aktów notarjalnych $i$ hipotecznych w gubernjach Królestwa Polskiego, Warszawa 1884.

[68] Strasburger E., Udzial Królestwa Polskiego w finansach Rosji, Warszawa 1918.

[69] Suligowski A., Warszawa i jej przedsiebiorstwa miejskie, Warszawa 1903.

[70] Sulikowski A., Krótki rys i zasady Towarzystwa Kredytowego Ziemskiego $w$ Królestwie Polskim $z$ dodaniem tablic rachunkowych obowiazujacych 
i wiadomości o skladzie osób wladz Towarzystwa Kredytowego Ziemskiego, Warszawa 1865.

[71] Szawlowski R., Najwyższe organy kontroli $w$ Polsce $w$ XIX wieku. Glówna Izba Obrachunkowa Ksiestwa Warszawskiego oraz Izba Obrachunkowa i Najwyższa Izba Obrachunkowa Królestwa Polskiego. Lata 1808-1866, Warszawa 1999.

[72] Szawlowski R., Najwyższy organ kontroli Królestwa Polskiego $w$ dobie Powstania Listopadowego 1830-1831, „Kontrola Państwowa” 1998, nr 6.

[73] Szawlowski R., Szefowie najwyższych organów kontroli w Polsce w XIX wieku: Franciszek Ksawery Zboiński $i$ nastepcy (lata 1808/9-1866), „Kontrola Państwowa” 1997, nr 4.

[74] Szumlański K., Wiadomość o funduszach na pożyczki dla budujqcych sie po miastach w Król[estwie] Polsk[im], „Biblioteka Warszawska” 1864 , t. 2.

[75] Tekely W. P., Polityczne i ekonomiczne przeslanki zniesienia granicy celnej pomiędzy Królestwem Polskim a Cesarstwem Rosyjskim, [w:] Studia $z$ historii państwa, prawa i idei - prace dedykowane Profesorowi Janowi Malarczykowi, red. A. Korobowicz i H. Olszewski, Lublin 1997.

[76] Tekely W. P., Rozmieszczenie komór celnych w Królestwie Polskim po zniesieniu granicy celnej pomiędzy Królestwem Polskim a Cesarstwem Rosyjskim, [w:] Studia z historii państwa, prawa, miast i Polonii - Ksiega dedykowana profesorowi Wladyslawowi Ćwikowi, red. J. Ciągwa, T. Opas, Rzeszów 1998.

[77] Tekely W. P., Sklad Sqdzacy Rady Stanu Królestwa Polskiego, jako najwyższy organ rozstrzygajacy sprawy celne (1861-1867), [w:] $Z$ dziejów wymiaru sprawiedliwości, tom Annales poświęcony pamięci twórców lubelskiego ośrodka historyczno-prawnego, „Annales UMCS” 1988, sectio G, vol. XXXV, 8 .

[78] Tekely W. P., Stanowisko Komisji Rzqdowej Przychodów i Skarbu w sprawie zniesienia granicy celnej pomiędzy Królestwem Polskim a Cesarstwem Rosyjskim, [w:] Przez tysiqclecia: państwo - prawo - jednostka, t. 1, Katowice 2001.

[79] Terlecki W., System monetarny Królestwa Kongresowego, „Wiadomości Numizmatyczne" 1960.

[80] Terlecki W., System monetarny Królestwa Polskiego po powstaniu listopadowym (1832-1842), „Wiadomości Numizmatyczne” 1966, z. 1.

[81] Trzetrzewiński W., O podatkach gruntowych stalych $w$ Królestwie Polskim obecnie istniejacych, Warszawa 1861.

[82] Wąsowicz M., Poczq̨tki Prokuratorii Generalnej Królestwa Polskiego, „Czasopismo Prawno-Historyczne” 1977, t. 29, z. 2.

[83] Wąsowicz M., Prokuratoria Generalna Królestwa Polskiego w latach 1816-1866/67, „Czasopismo Prawno-Historyczne” 1979, t. 31, z. 2. 
[84] Woliński J., Uwagi o brukowym $w$ mieście stolecznym Warszawie, Warszawa 1831.

[85] Wrotnowski A., Drogi handlowe w Królestwie Polskiem, „Biblioteka Warszawska" 1878, t. 3.

[86] Zdzitowiecki J., Ksiqże - minister Franciszek Ks. Drucki-Lubecki 1778-1846, Warszawa 1948.

[87] Zieliński F., Materialy do historii Towarzystwa Kredytowego Ziemskiego w Królestwie Polskim, „Ekonomista” 1866, nr 5; 1867, nr 4/5.

[88] Żóltowski S., Die Finanzen des Herzogsthums Warschau, Poznań 1892.

[89] Żukowski W., Dochody $i$ wydatki państwowe w Królestwie Polskim, Warszawa 1907.

- Wielkie Księstwo Poznańskie (Śląsk i Pomorze Gdańskie):

[1] Afeltowicz T., Studia nad historiq banków ślquskich. Do r. 1918, Wrocław 1963.

[2] Bagniewski A., Instytut kredytowy szlaski z roku 1835, „Biblioteka Warszawska" 1851, t. 3.

[3] Banzemer J., Ogólne uwagi nad urzqdzeniem kredytu dla nieruchomości miejskich, Berlin 1862.

[4] Chelmicki P., Przedmioty ogólnego interesu Towarzystwa Kredytowego, Poznań 1845.

[5] Komar A., Polityka podatkowa rzadu pruskiego $w$ Wielkim Ksiestwie Poznańskim w latach 1815-1870, „Studia i Materiały do Dziejów Wielkopolski i Pomorza" 1961, z. 2.

[6] Kościński K., Prawo podatkowe w Prusach. Podrecznik dla ludu polskiego, Poznań 1903.

[7] Kultys W., Finanse i podatki, [w:] Ksiega pamiqtkowa miasta Poznania, Poznań 1929.

[8] Kultys W., Slów kilka o zagadnieniu finansowo-skarbowym miast w Polsce ze specjalnym uwzglednieniem kwestii podatkowej miasta Poznania, „Kronika Miasta Poznania” 1927.

[9] Ochociński S., Poczq̨tki polskiej spóldzielczości kredytowej na Górnym Ślasku, „Kwartalnik Opolski” 1961, nr 1.

[10] Ochociński S., Polska spóldzielczość kredytowa na Pomorzu Gdańskim do 1918 r., „Zapiski Historyczne” 1963, t. 28, z. 2.

[11] [Zieliński F.] F. Z., Towarzystwo kredytowe miejskie na Szlasku, „Biblioteka Warszawska" 1844, t. 4.

[12] Zimmermann K., Die „Bank Przemyslowców” e[ine] G[esellschaft] $m$ [it] b[eschränkten] H[aftung] in Posen, ihre Gründung, Entwicklung und Bedeutung im Rahmen des „Verbandes der Erwebs- uns Wirtschaftsgenossenschaften im Grossherzogtum Posen und Westpreussen", Poznań 1907. 
Galicja - Wolne Miasto Kraków:

[1] Bieniarzówna J., Życie gospodarcze w Wolnym Mieście Krakowie, Kraków 1967.

[2] Biliński L., Opodatkowanie gminne, Lwów 1884.

[3] Biliński L., Studia nad podatkiem dochodowym, Lwów 1870.

[4] Buzek J., Administracja gospodarstwa spolecznego, Lwów 1913.

[5] Buzek J., Problem równowagi budżetu państwowego $w$ świetle statystyki finansowej, „Miesięcznik Statystyczny” 1923, z. 1.

[6] Czemeryński K., O dobrach koronnych bylej Rzeczypospoliiej Polskiej, Lwów 1870.

[7] Czerkawski W., Reforma podatku domowo-czynszowego, Kraków 1899.

[8] Dybiec J., Finansowanie nauki i oświaty w Galicji 1860-1918, Kraków 1979.

[9] Gargas Z., O podatku rentowym, Lwów 1898.

[10] Gargas Z., Studja nad kasami oszczędności, Lwów 1907.

[11] Gilewicz A., Stosunki pieniężne w Galicji w latach 1772-1914, „Rocznik Przemyski" 1958, t. 9.

[12] Głąbiński S., Finanse Galicji w r. 1894, „Przegląd Prawa i Adminstracji” 1894, nr 9.

[13] Gląbiński S., Finanse stol. m. Lwowa i projekt budżetu na r. 1891. Sprawozdanie jeneralne referenta miejskiej komisji budżetowej, Lwów 1901.

[14] Gląbiński S., Galicja w budżecie państwowym na rok 1904, „Przegląd Prawa i Administracji" 1904, t. 29.

[15] Gląbiński S., Samodzielność finansowa Galicji, Lwów 1906.

[16] Gląbiński S., Wyklad nauki skarbowości z dodatkiem skarbowości Austrii i Galicji, Lwów 1911.

[17] Kellmann R., Die ländlichen Kreditverhältnisse im ehemaligen Galizien und heutigen Polen unter besonderer Berücksichtigung des ländlichen Kreditgenossenschaftswesens, Saalfeld 1935.

[18] Kielbicka A., Kameralne urzędy gospodarcze w zachodniej Galicji, „Archeion" 1958, t. 29.

[19] Kleczyński J., O zakresie opodatkowania się gmin, „Przegląd Sądowy i Adminstracyjny" 1877, t. 2.

[20] Knolle I., Slówko z powodu banków kredytowych ziemskich, Żytomierz 1860.

[21] Kolankowski F., Podręcznik do bezpośrednich podatków osobistych wprowadzonych ustawa $z$ dn. 25 października 1896 r., nr $200 \mathrm{Dz}$. p. p., cz. I, Lwów 1897.

[22] Kolischer K., Organizacja kredytu w Galicji, Lwów 1900.

[23] Konitz H., Jeszcze w sprawie skarbowości gminnej, „Ekonomista” 1873, nr 14. 
[24] Kosch T., Wiadomości o należytościach skarbowych, ze szczególnym uwzglęnieniem praw wiejskich, Kraków 1903.

[25] Krobicki W., Rachunkowość w gminach wiejskich. Podrecznik o prowadzeniu ksiag $i$ rachunków gminnych wraz $z$ wzorami przepisanych druków, Lwów 1904.

[26] Krzeczunowicz K., $O$ podatku gruntowym i domowym $w$ Galicji, Kraków 1862.

[27] Leo J., Finanse Galicji oraz projekt reformy skarbu krajowego, Kraków 1889.

[28] Michalski J., Austriacki powszechny podatek zarobkowy, Kraków 1903.

[29] Michalski J., Plan finansowy ministra Bilińskiego, „Przegląd Prawa i Administracji” 1910, t. 35.

[30] Michalski J., Projekt reformy administracji a skarbowość, Kraków 1905.

[31] Michalski J., Uwagi w sprawie reformy finansów krajowych, „Przegląd Polski" 1907.

[32] Ostrożyński W., Galicyjskie Towarzystwo Kredytowe Ziemskie, jego powstanie i pólwiekowy rozwój, Lwów 1892.

[33] Paszkowski F., Reforma podatkowa, krótkie streszczenie i objaśnienie ustawy z dn. 25 października 1896r., nr 220 Dz. u. p. o bezpośrednich podatkach osobistych, ze szczególnym uwzglednieniem rolnictwa, $z$ dodaniem wyciagów z rozporzadzeń wykonawczych i formularzy zeznań podatkowych, Kraków 1897.

[34] Reich M., Podrecznik dla użtku w slużbie przy c. k. urzedach podatkowych, Przemyśl 1897.

[35] Rutkowski J., Galicyjski kataster gruntów jako podstawa statystyki wlasności ziemskiej, „Wiadomości Statystyczne o Stosunkach Krajowych” 1917, z. 3.

[36] Schrott J., Nauka rachunkowości państwowej dla krajów w Radzie państwa reprezentowanych $i$ dla spraw wspólnych wszystkim królestwom $i$ krajom monarchji austr.-węg., wyd. II popr., na jęz. polski przeł. i wlasnymi dopiskami uzupełnil T. Kulczycki, Lwów 1860.

[37] Sieprawski K., O opustach podatku gruntowego z powodu szkód elementarnych, Lwów 1900.

[38] Stupnicki H., Systematyczny uklad rozporzqdzeń we względzie myt drogowych, mostowych $i$ przewozowych, taks skarbowych, jako też i prywatnych, Lwów 1862.

[39] Styś W., Metryki gruntowe józefińskie i franciszkańskie jako źródlo do historii gospodarczej Galicji, „Roczniki Dziejów Społecznych i Gospodarczych" 1932-1933, t. 2.

[40] Tałasiewicz J., Wskazówki co do utrzymania zgodności między księami gruntowemi a katastrem na podstawie arkuszów zgloszeń udzielanych sqdom przez urzędy ewidencyjne katastra, Kraków 1898. 
[41] Tuleja J., W sprawie zniesienia akcyzy miejskiej od spirytusu denaturowanego, Kraków 1901.

[42] Udziela E., Podatek osobisto-dochodowy, „Czasopismo Prawnicze i Ekonomiczne" 1900.

[43] Wierzchlejski A., Wplyw cel na gospodarstwo spoleczne, „Ekonomista” 1902 , t. 3.

[44] Winhard J., Zarysy treściwe o podatkach, stemplach $i$ należytościach rzadowych $i$ funduszowych w państwie austriackim, a względnie w Galicji, Lwów 1897.

\section{3. [UJECCIE MERYTORYCZNE]}

Administracja:

[1] Buzek J., Administracja gospodarstwa spolecznego, Lwów 1913.

[2] Kielbicka A., Kameralne urzedy gospodarcze w zachodniej Galicji, „Archeion" 1958, t. 29.

[3] Kisiel H., Akta zarządu dóbr państwowych w Radomiu, „Archeion” 1962, t. 36.

[4] Markowski B., Administracja skarbowa w Polsce, Warszawa 1931.

[5] Michalski J., Projekt reformy administracji a skarbowość, Kraków 1905.

[6] Mirecki W., O prawodawstwie $i$ administracji finansowej, „Dekada Polska" 1821, t. 1, nr 4-6.

[7] Radziszewski H., Skarb $i$ organizacja wladz skarbowych $w$ Królestwie Polskim, t. 1 (1815-1830), t. 2 (1831-1867), Warszawa 1907 (t. 1), 1908 (t. 2).

[8] Radziszewski H., „Reorganizacya” skarbu Królestwa Polskiego po powstaniu listopadowym, „Przegląd Narodowy” 1908, t. 1, z. 4.

[9] Reich M., Podrecznik dla użytku w slużbie przy c. k. urzędach podatkowych, Przemyśl 1897.

[10] Rostocki W., Ludzie Colomba w Ministerium Skarbu u schylku Księstwa Warszawskiego, [w:] Wiek XIX, Warszawa 1967.

[11] Rybarski S., Skarbowość Polska $w$ dobie zaborów, Kraków 1937.

[12] Wąsowicz M., Poczq̨tki Prokuratorii Generalnej Królestwa Polskiego, „Czasopismo Prawno-Historyczne” 1977, t. 29, z. 2.

[13] Wąsowicz M., Prokuratoria Generalna Królestwa Polskiego w latach 1816-1866/67, „Czasopismo Prawno-Historyczne” 1979, t. 31, z. 2.

Banki, towarzystwa kredytowe i kasy oszczędności:

[1] Afeltowicz T., Studia nad historiq banków ślqskich. Do r. 1918, Wrocław 1963.

[2] Bagniewski A., Instytut kredytowy szlaski z roku 1835, „Biblioteka Warszawska" 1851, t. 3. 
[3] Bagniewski A., O zastosowaniu towarzystw kredytowych ziemskich do nieruchomości miejskich, mianowicie w mieście Warszawie, „Biblioteka Warszawska" 1842, t. 2.

[4] Bielski A., Projekt do ustawy kassy amortyzacyjnej, Rawicz 1811.

[5] Chelmicki P., Przedmioty ogólnego interesu Towarzystwa Kredytowego, Poznań 1845.

[6] Czermiński F., Towarzystwa kredytowe ziemskie ze szczególnym względem na takież towarzystwa $w$ Wielkim Ksiestwie Poznańskim, Królestwie $i$ Galicji, Warszawa 1867.

[7] Falkenhagen-Zaleski P., $O$ instytucjach kredytowych $w$ kraju naszym, Warszawa 1861.

[8] Gargas Z., Studja nad kasami oszczędności, Lwów 1907.

[9] Grodek A., Idea Banku Narodowego. (Geneza Banku Polskiego 1763-1828), Warszawa 1936.

[10] Groniowski K., Bank Wlościański w Królestwie Polskim, „Przegląd Historyczny" 1984, nr 1.

[11] Grzegorzewski M., Reforma kas gminnych pożyczkowo-oszczędnościowych w Królestwie Polskim, Kielce 1907.

[12] Jezierski A., Bankowość polska na tle przemian gospodarczych u schylku $X I X$ i na poczqtku $X X$ wieku, ,Bank i Kredyt” 2000, nr 11.

[13] Jezierski A., Bank Polski 1828-1885, „Bank i Kredyt” 1988, nr 5/6.

[14] Kirszrot-Prawnicki J., Towarzystwo Kredytowe Ziemskie w Królestwie Polskim i kredyt rolny, Warszawa 1887.

[15] Knolle I., Slówko z powodu banków kredytowych ziemskich, Żytomierz 1860.

[16] Kolischer K., Organizacja kredytu w Galicji, Lwów 1900.

[17] Korzybski Z., O kredycie $i$ bankach emisyjnych z zastosowaniem do potrzeb kraju naszego, Warszawa 1862.

[18] Kurc A., O kasach oszczędności, „Biblioteka Warszawska” 1842, t. 1.

[19] Mikulec B., Spóldzielcze towarzystwa pożyczkowo-oszczędnościowe i kredytowe w guberni lubelskiej w latach 1898-1914, „Rocznik Lubelski” $1985 / 86(1988)$, t. $27 / 28$.

[20] Ochociński S., Poczq̨tki polskiej spóldzielczości kredytowej na Górnym Ślqsku, „Kwartalnik Opolski” $1961 \mathrm{nr} 1$.

[21] Ochociński S., Polska spóldzielczość kredytowa na Pomorzu Gdańskim do 1918 r., "Zapiski Historyczne” 1963, t. 28, z. 2.

[22] Ostrożyński "W., Galicyjskie Towarzystwo Kredytowe Ziemskie, jego powstanie i pótwiekowy rozwój, Lwów 1892.

[23] Plewako G., Henryk hr. Lubieński i Benedykt Niepokojczycki - dwaj kierownicy Banku Polskiego. Przyczynek do dziejów tegoż Banku (1831-1865), „Niwa” 1887, t. 31. 
[24] Popiel I., Towarzystwo Kredytowe Ziemskie w Królestwie Polskim. Kilka uwag zebral..., Warszawa 1901.

[25] Radziszewski H., Bank Polski, Warszawa 1910.

[26] Radziszewski H., Reorganizacja Banku Polskiego po rewolucji listopadowej, „Przegląd Narodowy” 1910, t. 6, z. 7.

[27] Sulikowski A., Krótki rys i zasady Towarzystwa Kredytowego Ziemskiego $w$ Królestwie Polskim $z$ dodaniem tablic rachunkowych obowiazujacych $i$ wiadomości o skladzie osób władz Towarzystwa Kredytowego Ziemskiego, Warszawa 1865.

[28] Waszkiewicz J., Historya banków oraz celniejszych towarzystw kredytowych, Wilno 1838.

[29] Zamoyski G., Prawne podstawy funkcjonowania komunalnych kas oszczedności na ziemiach polskich $w$ okresie zaborów, [w:] Przez tysiaclecia: państwo - prawo - jednostka, t. 2, Katowice 2001.

[30] Zieliński F., Materialy do historii Towarzystwa Kredytowego Ziemskiego w Królestwie Polskim, „Ekonomista” 1866, nr 5; 1867, nr 4/5.

[31] [Zieliński F.] F. Z., Towarzystwo kredytowe miejskie na Szlasku, „Biblioteka Warszawska" 1844, t. 4.

[32] Zimmermann K., Die „Bank Przemyslowców” e[ine] G[esellschaft] m[it] b[eschränkten] H[aftung] in Posen, ihre Gründung, Entwicklung und Bedeutung im Rahmen des „Verbandes der Erwebs- uns Wirtschaftsgenossenschaften im Grossherzogtum Posen und Westpreussen", Poznań 1907.

- Problematyka celna:

[1] Budziński S., O stosowaniu ustawy celnej z r. 1857, a w szczególności art. 1621 i 1622 tejże ustawy, „Gazeta Sądowa” 1880, nr 48-50.

[2] Marcinek R., Komora celna w Szycach pod Krakowem, ,Teki Krakowskie” 1998, z. 8.

[3] Radziszewski H., Zniesienie linii celnej pomiędzy Królestwem Polskim a Cesarstwem Rosyjskim $w$ roku 1850, dodatek do: „Biblioteka Warszawska" 1907, nr 6.

[4] Tekely W. P., Polityczne i ekonomiczne przeslanki zniesienia granicy celnej pomiędzy Królestwem Polskim a Cesarstwem Rosyjskim, [w:] Studia $z$ historii państwa, prawa i idei-prace dedykowane Profesorowi Janowi Malarczykowi, red. A. Korobowicz, H. Olszewski, Lublin 1997.

[5] Tekely W. P., Rozmieszczenie komór celnych w Królestwie Polskim po zniesieniu granicy celnej pomiędzy Królestwem Polskim a Cesarstwem Rosyjskim, [w:] Studia z historii państwa, prawa, miast i Polonii - Ksiega dedykowana profesorowi Wladyslawowi Ćwikowi, red. J. Ciągwa, T. Opas, Rzeszów 1998.

[6] Tekely W. P., Sklad Sqdzacy Rady Stanu Królestwa Polskiego, jako najwyższy organ rozstrzygajacy sprawy celne (1861-1867), [w:] $Z$ dziejów 
wymiaru sprawiedliwości, tom Annales poświecony pamięci twórców lubelskiego ośrodka historyczno-prawnego, „Annales UMCS” 1988, sectio G, vol. XXXV, 8.

[7] Tekely W. P., Stanowisko Komisji Rzadowej Przychodów $i$ Skarbu w sprawie zniesienia granicy celnej pomiedzy Królestwem Polskim a Cesarstwem Rosyjskim, [w:] Przez tysiaclecia: państwo - prawo - jednostka, t. 1, Katowice 2001.

[8] Wierzchlejski A., Wplyw cel na gospodarstwo spoleczne, „Ekonomista" 1902 , t. 3.

- Kontrola skarbowa:

[1] Polujański A., Najwyższa Izba Obrachunkowa Królestwa Polskiego od 1808 do 1866 r. wlącznie, „Biblioteka Umiejętności Prawnych” 1880 , z. $42-44$.

[2] Szawlowski R., Najwyższe organy kontroli $w$ Polsce $w$ XIX wieku. Glówna Izba Obrachunkowa Księstwa Warszawskiego oraz Izba Obrachunkowa i Najwyższa Izba Obrachunkowa Królestwa Polskiego. Lata 1808-1866, Warszawa 1999.

[3] Szawłowski R., Najwyższy organ kontroli Królestwa Polskiego w dobie Powstania Listopadowego 1830-1831, „Kontrola Państwowa” 1998, nr 6.

[4] Szawłowski R., Szefowie najwyższych organów kontroli w Polsce $w X I X$ wieku: Franciszek Ksawery Zboinski $i$ nastepcy (lata 1808/9-1866), „Kontrola Państwowa” 1997, nr 4.

[5] Ziembiński J., Polska kontrola państwowa w XIX w. i w Drugiej Rzeczypospolitej, „Acta Universitatis Nicolai Copernici” 1985, Prawo, nr 24.

- Budzet, podatki i finanse:

[1] Bagniewski A., O stanie finansów Królestwa Polskiego, „Biblioteka Warszawska" 1861, t. 2

[2] Biliński L., Opodatkowanie gminne, Lwów 1884.

[3] Biliński L., Studia nad podatkiem dochodowym, Lwów 1870.

[4] Bloch J., Finanse Królestwa Polskiego za caly czas istnienia skarbu Królestwa od dnia 1 czerwca 1815 do 31 grudnia 1866 r. Zarzad, wladze skarbowe i reforma podatkowa w Królestwie Polskim, [w:] J. Bloch, Finanse Rosji w XIX wieku na tle cywilnych dziejów państwa, t. 3, Warszawa 1883.

[5] Bloch J., Reforma podatkowa w Królestwie Polskim podlug badań..., „Ekonomista" 1879, nr 48-52.

[6] Borzymińska Z., Sprawa podatku szynkarskiego w Warszawie w latach 1862-1866, „Biuletyn ŻlH” 1988, nr 2.

[7] Bossakowski J., Gospodarka $i$ finanse Królestwa Polskiego przed powstaniem styczniowym. Raport... z $1862 \mathrm{r}$. dla ministra finansów $M$. Ch. Reuterna, oprac. R. Kołodziejczyk, Warszawa 1969. 
[8] Boufall B., Gospodarka finansowa zarzqdów miejskich w Królestwie Polskim (z wyjatkiem Warszawy), Warszawa 1905.

[9] Buzek J., Problem równowagi budżetu państwowego w świetle statystyki finansowej, „Miesięcznik Statystyczny” 1923, z. 1.

[10] Czerkawski W., Reforma podatku domowo-czynszowego, Kraków 1899.

[11] Cwik W., Sprawa oplat za prawo miejskie w Królestwie Polskim, „Czasopismo Prawno-Historyczne” 1972, t. 24, z. 1.

[12] Dybiec J., Finansowanie nauki $i$ oświaty w Galicji 1860-1918, Kraków 1979.

[13] Gargas Z., O podatku rentowym, Lwów 1898.

[14] Gilewicz A., Stosunki pienieżne w Galicji w latach 1772-1914, „Rocznik Przemyski" 1958, t. 9.

[15] Gliszczyński A., Uwagi nad dochodami publicznymi, Warszawa 1810.

[16] Gliszczyński A., Uwagi nad projektem amortyzacji dlugów ziemiańskich $w$ departamencie bydgoskim, Bydgoszcz 1811.

[17] Gląbiński S., Finanse Galicji w r. 1894, „Przegląd Prawa i Administracji” 1894, $\mathrm{nr} 9$.

[18] Gląbiński S., Finanse stol. m. Lwowa i projekt budżetu na r. 1891. Sprawozdanie jeneralne referenta miejskiej komisji budżetowej, Lwów 1901.

[19] Gląbiński S., Galicja w budzecie państwowym na rok 1904, „Przegląd Prawa i Administracji" 1904, nr 29.

[20] Gląbiński S., Samodzielność finansowa Galicji, Lwów 1906.

[21] Górski S., Gospodarka finansowa miasta Warszawy, dodatek do: „Biblioteka Warszawska" 1906, $\mathrm{nr}$ 6, 7.

[22] Grabski W., Bilans Królestwa Polskiego w finansach państwa rosyjskiego, Warszawa 1909.

[23] Grabski W., Sprawa podatku od dochodu z nieruchomości miejskich w Królestwie Polskim, Praca nr 5, dodatek do: „Biblioteka Warszawska” 1909 , t. 3.

[24] Jaworski J., Gospodarka finansowa zarzq̨ów miejskich w Królestwie Polskim z wylaczeniem Warszawy, Warszawa 1906.

[25] Karbownik H., Opodatkowanie duchowieństwa i dóbr kościelnych w Królestwie Polskim (1815-1863), „Roczniki Teologiczno-Kanoniczne” 1989/90 (1993), nr 36/37, z. 5 .

[26] Kellmann R., Die ländlichen Kreditverhältnisse im ehemaligen Galizien und heutigen Polen unter besonderer Berücksichtigung des ländlichen Kreditgenossenschaftswesens, Saalfeld 1935.

[27] Kempner S., Prawa stanowe kupców w Królestwie Polskim, w zwiq̨zku $z$ prawodawstwem podatkowym, „Gazeta Sądowa” 1899, nr 8-10.

[28] Kleczyński J., $O$ zakresie opodatkowania się gmin, „Przegląd Sądowy i Administracyjny" 1877, t. 2. 
[29] Kolankowski F., Podrẹcznik do bezpośrednich podatków osobistych wprowadzonych ustawq $z$ dn. 25 października 1896 r., nr 200 Dz. p. p., $c z$. I, Lwów 1897.

[30] Komar A., Polityka podatkowa rząu pruskiego w Wielkim Ksiestwie Poznańskim w latach 1815-1870, „Studia i Materiały do Dziejów Wielkopolski i Pomorza" 1961, z. 2.

[31] Konitz H., Jeszcze w sprawie skarbowości gminnej, „Ekonomista” 1873 , nr 14.

[32] Kosch T., Wiadomości o należytościach skarbowych, ze szczególnym uwzglednieniem praw wiejskich, Kraków 1903.

[33] Kościński K., Prawo podatkowe w Prusach. Podrecznik dla ludu polskiego, Poznań 1903.

[34] Krobicki W., Rachunkowość w gminach wiejskich. Podrecznik o prowadzeniu ksiqg $i$ rachunków gminnych wraz $z$ wzorami przepisanych druków, Lwów 1904.

[35] Krzeczunowicz K., O podatku gruntowym i domowym w Galicji, Kraków 1862.

[36] Kultys W., Finanse i podatki, [w:] Ksiega pamiqtkowa miasta Poznania, Poznań 1929.

[37] Kultys W., Slów kilka o zagadnieniu finansowo-skarbowym miast w Polsce ze specjalnym uwzglednieniem kwestii podatkowej miasta Poznania, „Kronika Miasta Poznania” 1927, R. V.

[38] Leo J., Finanse Galicji oraz projekt reformy skarbu krajowego, Kraków 1889.

[39] Markowski B., Finanse miast Królestwa Polskiego, t. 1, Kielce 1913.

[40] Mayzel B., Nowy podatek, „Gazeta Sądowa” 1879, nr 27-31.

[41] Michalski J., Austriacki powszechny podatek zarobkowy, Kraków 1903.

[42] Michalski J., Plan finansowy ministra Bilińskiego, „Przegląd Prawa i Administracji" 1910, t. 35.

[43] Michalski J., Uwagi w sprawie reformy finansów krajowych, „Przegląd Polski" 1907.

[44] Mikulicz-Radecki A., O podatku gruntowym dworskim $w$ Królestwie Polskiem, Warszawa 1884.

[45] Paszkowski F., Reforma podatkowa, krótkie streszczenie $i$ objaśnienie ustawy z dn. 25 pażdziernika 1896r., nr 220 Dz. u. p. o bezpośrednich podatkach osobistych, ze szczególnym uwzglednieniem rolnictwa, $z$ dodaniem wyciagów z rozporzqdzeń wykonawczych i formularzy zeznań podatkowych, Kraków 1897.

[46] Polujański A., Przepisy tyczq̨e sie egzekucji podatków w Królestwie Polskim, Warszawa 1883.

[47] Powichrowski W., O powinności podwodowej w Królestwie Polskim, „Gazeta Sądowa” 1893, nr 6, 7, 10. 
[48] Przygodzki J., Sprawy finansowe Ksiestwa Warszawskiego pod okupacja rosyjskq w latach 1813-1815, „Acta Universitatis Wratislaviensis” 2000, Prawo, nr 270.

[49] Radziszewski H., Podatki gruntowe w Królestwie Polskim, [w:] W naszych sprawach, t. 1, Warszawa 1899.

[50] Radziszewski H., Wydatki skarbu Królestwa Polskiego w okresie międzypowstaniowym, „Przegląd Narodowy” 1908, t. 2, z. 7.

[51] Rostworowski M., Prawno-polityczna strona budzetów Królestwa Kongresowego (1816-1830), „Czasopismo Prawnicze i Ekonomiczne” 1905, t. 6.

[52] Sieprawski K., O opustach podatku gruntowego z powodu szkód elementarnych, Lwów 1900.

[53] Strasburger E., Udzial Królestwa Polskiego w finansach Rosji, Warszawa 1918.

[54] Trzetrzewiński W., O podatkach gruntowych stalych w Królestwie Polskim obecnie istniejacych, Warszawa 1861.

[55] Tuleja J., $W$ sprawie zniesienia akcyzy miejskiej od spirytusu denaturowanego, Kraków 1901.

[56] Udziela E., Podatek osobisto dochodowy, „Czasopismo Prawnicze i Ekonomiczne" 1900.

[57] Winhard J., Zarysy treściwe o podatkach, stemplach $i$ należytościach rzqdowych $i$ funduszowych $w$ państwie austriackim, a względnie $w$ Galicji, Lwów 1897.

[58] Woliński J., Uwagi o brukowym w mieście stolecznym Warszawie, Warszawa 1831.

[59] Zieliński F., Poszukiwania nad finansami w Polsce, „Biblioteka Warszawska" 1849.

[60] Żóltowski S., Die Finanzen des Herzogsthums Warschau, Poznań 1892.

[61] Żukowski W., Dochody $i$ wydatki państwowe w Królestwie Polskim, Warszawa 1907.

- Inne:

[1] Ajzen M., Polityka gospodarcza Lubeckiego 1821-1830, Warszawa 1932.

[2] Bagniewski A., O mennicy warszawskiej od czasu jej zalożenia (1810) do roku 1867, ze szczególnym względem na monete zdawkowa, „Ekonomista" 1869 , t. 1.

[3] Baliński I., Loterie publiczne w Polsce. Szkic historyczny, Warszawa 1918.

[4] Banzemer J., Ogólne uwagi nad urzq̨dzeniem kredytu dla nieruchomości miejskich, Berlin 1862.

[5] Bielski A., Sposoby do ocalenia majątków obywateli Ksiestwa Warszawskiego, Kalisz 1809.

[6] Bieniarzówna J., Życie gospodarcze w Wolnym Mieście Krakowie, Kraków 1967. 
[7] Czemeryński K., O dobrach koronnych bylej Rzeczypospolitej Polskiej, Lwów 1870.

[8] Gąbiński S., Wyklad nauki skarbowości z dodatkiem skarbowości Austrii i Galicji, Lwów 1911.

[9] Grabski W., Cįżary samorzq̨u w Królestwie Polskim, Warszawa 1908.

[10] Grabski W., Dzialalność państwowa wobec potrzeb rolniczych Królestwa Polskiego. Co skarb państwa w naszym kraju na cele rolnicze wydaje i czego domagać się winniśmy i możemy, Warszawa 1909.

[11] Kula W., Polskie perypetie metrologiczne (1795-1919), [w:] Wiek XIX. Prace ofiarowane $S$. Kieniewiczowi w 60 rocznice urodzin, Warszawa 1967.

[12] Kurtz A., O cyrkulacji pieniężnej w Królestwie Polskim, „Ekonomista” 1865 kwart. 4, z. 1. [Miaskowski F.] F. M., Odpowiedź na memorial pana Adolfa Kurtza, O cyrkulacji pienięznej w Królestwie Polskim, zamieszczony w I-m i III-m zeszycie Ekonomisty, „Ekonomista” 1865, kwart. 4, z. 3.

[13] Kurtz A., Rzecz o cyrkulacji pieniężnej $i$ walucie w Królestwie Polskim, Warszawa 1866.

[14] Lewin D., Obieg pienięzny Królestwa kongresowego $w$ drugiej polowie $X I X$ stulecia, „Rocznik Wyższej Szkoły Handlowej w Warszawie" 1929, R. VI.

[15] Lętowski L., O moratoryum, Warszawa 1816.

[16] Polujański A., Opisanie lasów Królestwa Polskiego i guberni zachodnich Cesarstwa Rosyjskiego pod względem historycznym, statystycznym i gospodarczym, t. 1-4, Warszawa 1854-1855.

[17] Rembowski A., Nowe prawo o urzq̨dzeniu gruntowym wiejskich czynszowników, „Niwa” 15 I 1880.

[18] Romanowski J., Rys stosunków ekonomicznych guberni radomskiej na podstawie akt hipoteki gubernialnej $i$ akt notaryalnych $w$ Radomiu, Warszawa 1892.

[19] Rutkowski J., Galicyjski kataster gruntów jako podstawa statystyki wlasności ziemskiej, „Wiadomości Statystyczne o Stosunkach Krajowych” 1917, z. 3.

[20] Rzepniewska D., Dobry kredyt i lichwa w Królestwie Polskim XIX w., [w:] Drobnomieszczaństwo XIX i XX wieku, t. 1, Warszawa 1984.

[21] Schrott J., Nauka rachunkowości państwowej dla krajów w Radzie państwa reprezentowanych $i$ dla spraw wspólnych wszystkim królestwom i krajom monarchji austr.-węg., wyd. II popr., na jęz. polski przełożył i wlasnymi dopiskami uzupełnił T. Kulczycki, Lwów 1860.

[22] Skarbek F., Gospodarstwo narodowe stosowane, Warszawa 1860.

[23] Skarbek F., Gospodarstwo narodowe, Warszawa, 1820/21.

[24] Stankiewicz Z., Reformy czynszowe dóbr skarbowych w Królestwie Polskim, Lódź 1968. 
[25] Stankiewicz Z., System eksploatacji dóbr publicznych w Polsce środkowej $w$ okresie przejścia od feudalizmu do kapitalizmu, „Czasopismo Prawno-Historyczne" 1970, t. 22, z. 2.

[26] Stanulewicz M., Polityka fiskalna wladz powstania styczniowego w świetle dekretów Rzqdu Narodowego, [w:] Studia $z$ historii ustroju i prawa. Ksiega dedykowana Prof. Jerzemu Walachowiczowi, red. H. Olszewski, Poznań 2002.

[27] Stawiarski J. F., Uwagi nad moratorium, Warszawa 1816.

[28] Strasburger A., Podrecznik o kosztach stemplowych $i$ innych oplatach, wnoszonych od dn. 1 maja 1884 r. przy sporzqdzaniu aktów notarjalnych $i$ hipotecznych $w$ gubernjach Królestwa Polskiego, Warszawa 1884.

[29] Stupnicki H., Systematyczny uklad rozporzqdzeń we względzie myt drogowych, mostowych $i$ przewozowych, taks skarbowych, jako też i prywatnych, Lwów 1862.

[30] Styś W., Metryki gruntowe józefińskie i franciszkańskie jako źródlo do historii gospodarczej Galicji, „Roczniki Dziejów Społecznych i Gospodarczych" 1932-1933, t. 2.

[31] Suligowski A., Warszawa i jej przedsiebiorstwa miejskie, Warszawa 1903.

[32] Szumlański K., Wiadomość o funduszach na pożyczki dla budujacych sie po miastach w Król[estwie] Polsk[im], „Biblioteka Warszawska” 1864 , t. 2.

[33] Tałasiewicz J., Wskazówki co do utrzymania zgodności między księami gruntowemi a katastrem na podstawie arkuszów zgloszeń udzielanych sqdom przez urzędy ewidencyjne katastra, Kraków 1898.

[34] Terlecki W., System monetarny Królestwa Kongresowego, „Wiadomości Numizmatyczne" 1960, t. 4.

[35] Terlecki W., System monetarny Królestwa Polskiego po powstaniu listopadowym (1832-1842), „Wiadomości Numizmatyczne” 1966, z. 1.

[36] Wrotnowski A., Drogi handlowe w Królestwie Polskiem, „Biblioteka Warszawska" 1878, t. 3.

[37] Zdzitowiecki J., Ksiąze - minister Franciszek Ks. Drucki-Lubecki 1778-1846, Warszawa 1948. 